Antonio Ortuño - Ela Varošanec

\title{
Bitka kod Hastingsa
}

Mrtvi osvjetljavaju put živima. Zato čitamo: da upalimo baklju. Uz njezino svjetlo pišemo. To vam govorim uvjerenošću voditelja radionice kreativnog pisanja, četrdesetogodišnjaka, s obiteljskim problemima, čovjeka koji je više star nego mlad (to ne vrijedi za sve četrdesetogodišnjake, ali u mom je slučaju istina), koji stoji ispred grupe muškaraca koji izgledaju kao glumačka postava poznatog filma o velikoj pobjedi grupe nespretnjakovića. Ovima, dečkima s radionice, nedostaje cijeli niz prijeko potrebnih stvari: ruka, osobna higijena, samopouzdanje, minerali, elektroliti. Nemojte kriviti pisanje. Na kraju krajeva, svima nama koji pišemo u određenoj mjeri, svakog jutra, nedostaje jedna ruka.

Aura, moja žena, prestala mi je odgovarati na poruke sat vremena prije početka radionica. A poruke koje su stigle prije nego što je nastupila tišina bile su pune grubog prijezira. Nešto sam napravio; nešto, ponavljam kako bih izbjegao mučno razmišljanje. Uzrok nezadovoljstva može biti konkretan ili apstraktan, ideološki ili to što sam se vratio pijan, u zoru, i srušio vazu kada sam bacio jaknu na stol.

Englesku su zvali „neosvojivi otok“. To je, dečki moji, laž. Osvojili su je, čini mi se, svi osim Napoleona i Hitlera. Kelti su sjebali Pikte. Rimljani Kelte. Sasi Rimljane. Vikinzi sve ostale. Ali Engleska, zapravo, nije bila Engleska sve dok jednog jutra nisu stigli Normani i odlučili ondje ostati. Stvar se zapliće. Tko su, dovraga, Normani? Isto Vikinzi, ali ovi su nastanjivali sjever Franačke. Nord-mand, ljudi sa sjevera. Otvorite pretraživač, prebacite na „Slike“ i pogledajte in: zašiljene kacige sa štitnikom za nos, ovalni štitovi, koplja za hvatanje divljih svinja, verižnjače duge kao hokejski dres. Možda netko od vas upravo sada u pretraživaču gleda njihov najpoznatiji prikaz, slavnu Tapiseriju iz Bayeuxa, koja potječe iz tog vremena, a koju je prema nekim izvorima izvezla sama kraljica Matilda, žena Vilima Osvajača, normandijskog plemića koji je izvršio invaziju na Englesku (drugi kažu da ju je zapravo naručio njegov polubrat Odo, koji je bio biskup, ali, iskreno, 
nije nas briga). Te zvijeri krvi i željeza, bili su, dakle, Normani, i njima ćemo posvetiti današnju radionicu.

Omela me nova Aurina poruka i strah me onoga što bi u njoj moglo pisati. Strah me onoga što znam da piše. Jučer sam, kao i svakog četvrtka, izašao s prijateljima i pio sve dok mi svijest nije postala elastična, lagana, savitljiva. Možda to i ne bi bio problem da, nakon što sam se izborio s ključem i tresnuo vratima, nakon što sam uzeo čašu vode i zalio si cipele, nisam shvatio da mi je vruće. Znojna neugoda, paklena zagušljivost. Bacio sam jaknu na stol kao da odbacujem iskušenje i grijeh, i tako sam razbio ljubičastu staklenu vazicu koju smo nakon sprovoda donijeli iz kuće moje mame. Pad vaze bio je i moj pad, a prasak je nagnao moju ženu da izađe iz dvorca strpljenja u koji se sklanja, već mjesecima, da preživi oluju. Zbog toga sam spavao u dnevnom boravku, a moj je mobitel bio preplavljen propovijedima. Bolje Engleska.

Vilim Osvajač iskrcao se na južnu obalu otoka. Sasi su mu došli u susret i njihove su se vojske suočile na poljima Hastingsa. I ovdje sve postaje čudno. Normani su, kaže povjesničar William iz Malmesburyja, u bitku ušli pjevajući. Nije li to prekrasno? Pjevali su, na francuskom, franačku narodnu pjesmu; pjesmu onih s kojima nisu imali nikakve veze, i koje su, djelomično, porazili i oteli im dio Normandije. Pjevali su Chanson de Roland. El cantar de Roldán na španjolskom. Da, već su tada Španjolci jako slobodno prevodili naslove. Jeste li znali da su Some Like It Hot preveli kao U suknjama i bez pameti?

Da sažmemo: Sasi će izgubiti kraljevstvo u borbi protiv osvajača koji su potekli od Vikinga, koji nisu Franci, ali su - kakve li ljepote - ušli u bitku podižući si moral Chansonom. Rolandovom ili Roldánovom, svejedno. Pjevali su i borili se kao lavovi, sjajni na popodnevnom suncu. Tim se prizorima, vidim, ne divite onoliko koliko biste trebali. Vjerujem, i nemojte mi raditi te face kao da ste suci Haškog suda, da je stari rat bio lijep. Ne kada se dogodio, nego kada su o njemu pjevali. Bolje je da imamo llijadu, Arhilohov štit i Eneidu, da imamo Cida i Rolanda, nego da ih nemamo. Rat može postati ljepota samo uz pomoć laži, znam, ali tako je i sa životom. Vi to nazivate da vanjem smisla: ja to zovem laž. Ali imam za to još jedno ime, a ovo bi vas trebalo zanimati da konačno nešto dobijete za taj novac koji ste uložili u radionicu - zovem to i pisanjem.

U novoj Aurinoj poruci piše da uz njezin posao, sve kućne poslove i njezine osobne probleme, moj alkoholizam u nastajanju prijeti svemu što imamo, kao invazija brodova na obzoru, i ona ima 
osjećaj kao da ne cijenim sve što radi kako bi izbjegla naše potonuće i da sam odlučan u tome da se razbolim, klonem, uvenem. Ne odgovaram jer ne bih mogao artikulirati neki pristojan odgovor a da dečki ne primijete da tipkam, pa ignoriram poruke, ali više ne mislim ni na prodiku o Normanima, nego uranjam u blato koje je život, danas. Usrani dan, samo jedan usrani dan. Kad bih mogao objasniti kako se osjećam, Aura bi sigurno bila sretna. Sigurno bi joj glava eksplodirala od sreće i zadovoljstva, oči bi joj iskočile iz duplji od čiste euforije, i grčila bi se obuzeta nepriličnim, kozmičkim, nemjerljivim orgazmom, kada bih joj samo mogao objasniti da je ona jedino zbog čega se nisam popeo na zadnji kat neke zgrade, najviše u ovom gradu patuljastih zgrada, otišao do prozora i skočio.

Ali moram se maknuti od telefona jer držim jako važno i stručno predavanje, praćen grubim i pomalo dječačkim pogledima skupine mladića, slomljenih, nepotpunih, uvrnutih. Pretpostavljam da zato pišu umjesto da šeću po trgovačkim centrima ili naslonjeni na šank u nekom bircu sklapaju nova prijateljstva. I njima bih želio objasniti da silno volim njihove uplate, zato što mi omogućuju da platim tae kwon do svojim kćerima, i da obožavam njihove tekstove jer su najbolje što su stvorili iako su užasni, jezivi i nijedan ih urednik ne bi shvatio ozbiljno. I da su, uz to, i oni sami krasni, ispod tih prištića i naočala s debelim staklima i odjeće oprane previše puta. Krasni su ako su siromašni i pišu, kao što sam i ja nekad, iz gnjeva. I predivni su ako su bogati i žele se boriti u klasnom ratu na pogrešnoj strani (te tako, kada izgube, svejedno pobjeđuju).

Moj najbolji učenik mračni je bradati tip, kao od stijene odvaljen, a bavi se prodajom piratske robe i preprodajom raznih artikala iz Kine. Na uvodnom predavanju priznao je da je švorc, bez prebijene pare, da je završio dvije knjige koje nijedan urednik nije pročitao, a nisu ih pročitali ni klauni ulizice iz izdavačkih kuća koji su ih trebali barem prelistati prije nego što su mu poslali odbijenice. Dvije knjige koje, posljedično, nisu pročitale ni prekrasne cure koje su mu trebale pasti u naručje ili, još bolje, raspravljati s njim o svojstvima pridjeva. Ova, ova koju sad pišem, moj je zadnji pokušaj i nakon toga sve šaljem u kurac, rekao je usred uvodnog predavanja, posvetit ću se ribarenju, odštopavanju cijevi ili ću postati mesar. Ali nešto ga je zadržavalo: majka mu je bila ostavila životno osiguranje, novac od kojeg je bez posla mogao živjeti šest ili možda, bude li štedljiv, osam mjeseci. Ne znam bih li trebao staviti sve na kocku, sjesti i napisati tu knjigu koja mi dahće za vrat, koju nosim ispod noktiju i kapaka, koja mi je kao metla zabijena u guzicu, koja mi je zapela u grlu i 
koju noćima sanjam, rekao je kada se upisivao. I vi ste, učitelju, pretpostavljam, u nekom trenutku sve stavili na kocku. Pa mi recite: što biste vi napravili? Izgubiti posljednje što mi je ostalo ili to sačuvati i posvetiti se ribarenju, cijevima punim govana, mesarenju?

Bori se, rekao sam mu jer je bio četvrtak i napit ću se kada izađem odande. Bori se, pjevaj i bori se, dovraga. Zato smo ovdje.

Požalim, ponekad, što sam ovdje.

Normani su išli u bitku s Chanson de Roland u grlima zato što je Franačka malo uljudila ono vikinško u njima, zato što je to bila prekrasna poema od koje bi im uzavrela krv i koja in je poticala da umru uzvišenom smrću u nadi da će i njih opjevati. Umrijeti da bi živio, te pizdarije koje su rado govorili ratnici. Ali Chanson im nije pripadala. Kaže enciklopedija, a potvrđuje prolog izdanja koji imam kod kuće, da ju je napisao opat Turold, negdje oko 1170., gotovo četiri stoljeća nakon što su se odvili događaji koje opisuje. Ili koje se pravi da opisuje, jer je cijela Chanson de Roland jedna ogavna laž.

Kao što je laž i da je Turold bio originalni autor. Zna se, zahvaljujući već spomenutom gospodinu Malmesburyju, da su Normani ušli u Hastings pjevajući je... cijelo stoljeće prije nego što je, prema izračunima, nastao Turoldov rukopis (koji još postoji i čuva se u Oxfordu). Dámaso Alonso, pjesnik, to je i dokazao: otkrio je u jednom samostanu senzacionalna imena (Sveti Emilio od Kapuljače, tako se zove mjesto, tako mi presvetog prepucija) bilješku koja datira iz sredine 11. stoljeća i sadrži sažetu verziju priče iz Chansone. Sigurno je, dakle, da Rolandovi korijeni sežu mnogo ranije od vremena Turolda, opata prepisivača. Možda potječu iz vremena kada su kraljevali nasljednici Karla Velikog, franačkog vladara iz razdoblja kad su se odigrali događaji izmišljeni u poemi.

Ali hajmo se uhvatiti ukoštac s laži i obmanom. Postavimo to ovako. Zamislite, a to je stvarno lako, barda, bilo kojeg, koji si večernji obrok priskrbljuje dodvoravajući se skupini seoskih plemenitaša herojskom poemom o prošlim vremenima, i, naravno, ne izmišlja on svoje priče ni iz čega, nego ih oblikuje miješajući stare priče iz narodne predaje. Pravi je plaćenik, taj naš bard, koji se ne zamara time što hrabrog Rolanda nije iz zasjede napala i ubila vojska Saracena, kako će cinično opjevati, nego su ga kamenovali Vaskonci, ljutiti zbog toga što im je Karlo Veliki opustošio Pamplonu. Vidite li sada otkad još krive muslimane za sve što se dogodi? 
U pičku materinu, dobro znam da je zamršeno. U manje od pola sata Normani, Sasi, Franci, Saraceni, Vaskonci, a moji učenici, zgodni, ali pomalo uvrnuti, gledaju me kao da razumiju, ali, većinom, razumiju manje nego što bi razumjeli da im držim predavanje iz nuklearne fizike. O, i nemojmo zaboraviti Aurine razorne poruke u telefonu. I sram.

Moj bradati učenik nije se uspio ubio, ali da je barem jest. Vozeći se na svom motociklu, patetično starom, ali još uvijek u voznom stanju, koji je bez problema mogao dogurati do sto dvadeset, a služio mu je, uglavnom, za dostavu narudžbi kineske robe, popeo se na nadvožnjak i izgubio kontrolu. Motor je uletio u stan u blizini zaštitne ograde (kada ti soba tako postane dio avenijskog krajobraza, sigurno naposljetku jasno vidiš rezultate unapređenja cestovne infrastrukture), a moj je učenik padao kao kakvo prokletstvo sve dok se nije razbio o haubu gradskog autobusa. U džepu jakne nosio je odbijenicu za svoj novi rukopis. Razina alkohola u krvi bila je visoka, no ništa strašno, ali nisu pronađeni tragovi lijekova ili ilegalnih supstanci. Možda mu se samo zavrtjelo u glavi. Vrag će ga znati. Nije umro, ali zglob na lijevoj ruci pretvorio mu se u kašu, a njegova svijest, rastezljiva poput gume, sakrila se iza kapaka.

Morali su mu amputirati dio ruke i vatra se ugasila. Ali ipak: tek što se oporavio (koliko se već uopće mogao oporaviti), vratio se na radionicu. Ponekad se žali na bol koju osjeća u podlaktici. Osmijeh mu je topao kao sunce, ali ako ga netko nešto pita, okrene se prema zidu. Ušteđevina mu se topi, a socijalno je takvo kakvo je, dostaje za sklopivi krevet i patronažnu sestru koja ga posjećuje jednom u dva tjedna. Shvaćam da je upropašten, ali ga volim jer je hrabar, kao lav. Norman. I dalje je na nogama i pogledom prati svaki moj pokret, iako skriva lice ako ga pokušam pogledati u oči.

Aura, odjednom, šalje poruku ne spominjući našu bitku kod Hastingsa. „U subotu je godišnjica tvojoj majci." I odgovaram da znam, da već godinu dana znam da će doći, ali to ne kažem, samo potvrdim i pitam što ćemo napraviti i ona sada šuti, kao da razmišlja o tome. „Odnijet ćemo joj cvijeće“, na kraju odlučuje.

Gledam usredotočena lica svojih učenika, tako osakaćena i lijepa i pomislim da je možda za danas dosta, da je bilo dovoljno o poljima mrtvaca i oklopima nezamislivim na ovim vrućinama. Ali ne: nije dovoljno. Ako ne nauče biti manje loši, proždrijet će in žive. Kao što su proždrli našeg bradonju, 
koji je pisao kao anđeo i, na kraju, ne samo da je izgubio ruku, nego sada dolazi svaki tjedan i gleda nas svojim praznim osmijehom i skriva pogled i ima batrljak i, naravno, prestao je pisati. Pisati znači zaplesti se u paukovu mrežu i ne moći se više ispetljati, kažem vam, ali ponekad se čovjek uplete i ostane kao oduzet jer to je to, više mu nema pomoći.

Mi smo bardovi plaćenici koji zapisuju što čuju da bismo napisano prodali jadnicima koji za to mogu platiti. Mi smo lažljivci koji ukrašavamo, glancamo, izobličujemo, odvratno uljepšavamo i uljuđujemo, čak i kada pokušavamo prikazati kaljužu. Dečki sada napeto slušaju i čak i moj voljeni bradati učenik ima sjaj u oku koji se ne može pripisati antidepresivima. Mi smo bezvrijedni osvajači i egoisti koji se ohrabruju podupirući se lažljivom ljepotom, koja nam ne pripada i nije zamišljena za nas. Laž i uzurpacija stvarno jesu sugestivne, stvarno jesu prekrasne i varljive, tjeraju nam suze na oči i glazbu u grlo. Pisanje je pokušaj obmane, kažem im i ustajem i rukom obgrlim golema ramena bradonje, koji me konačno mora pogledati, poluotvorenih usta. Pisati znači izmišljati tko smo i zašto smo na ovom prljavom polju, s mačem u rukama i verižnjačom koja nalikuje na hokejski dres, i znači pronaći u apsolutnoj laži razloge da krenemo u juriš protiv stampeda luđaka. I podižem batrljak našeg dečka kao da ga proglašavam pobjednikom boksačkog meča. A ako to učinimo dobro i uz malo sreće, naša će se plaćenička pjesma pjevati i tjerat će suze na oči budućim osvajačima, i nagnat će ih da izađu na bojno polje zaogrnuti ljepotom i da se bore kao lavovi, prekrasni i sjajni kao kipovi ili zastave (lavovi zapravo zaudaraju, njihovo krzno je prljavo i puno parazita i krvavih krasta). Ili će nas same nagnati u boj. Nismo ovamo došli pisati, dame i gospodo, zvijeri i demoni: došli smo rezati grla.

Bradonja tiho zacvili, a ja i dalje držim njegov batrljak u zraku i, premda ga možda boli, on ispusti uzdah koji nalikuje na uvjerenost i, prema tome, na sreću. Taj tvoj jebeni rukopis čisto je zlato, i ubit ćemo svakog koga treba ubiti kako bi cijeli svijet to saznao, šapnem mu, iako ga nisam pročitao, naravno, ali sada u sebi odlučujem da ću konačno otvoriti prokletu poruku koju mi je poslao prije ne znam koliko mjeseci i baciti oko na dokument.

Pobijedit ćemo i Engleska će biti naša. Ili ćemo umrijeti pod nepreglednim valom neprijatelja i netko, u nekoj budućnosti koju je nemoguće zamisliti, opjevat će nas.

Lažite, varajte. 
I još lažite.

Završavamo sat i izlazimo u hodnik kao da idemo u bitku. Neki me grle prije nego što odu.

Iskoristim to da ih podsjetim da je vrijeme da mi plate i oni plaćaju, ravnaju novčanice i, s olakšanjem, istrčavaju na ulicu da pričekaju javni prijevoz, hodaju, ili čak da sjednu u svoje automobile, nagaze na gas, riskiraju svoje ekstremitete.

Volim ih, zaista ih volim.

Bradonja je nestao iz učionice.

Sam sam pod svjetlom štedne žarulje, stisnutih šaka, suhih usta i osjećam peckanje u grlu, možda od srama. A možda je početak infekcije.

Dobio sam poruku od Aure.

Otvorit ću je.

Ali ne sada.

Sad ću prvo sjesti, duboko udahnuti, i lagati i lagati.

\section{(c) (i) (3)}

Creative Commons Attribution-NonCommercial-NoDerivatives 4.0 International License 